\title{
PENGARUH DIET BEBAS GLUTEN DAN KASEIN TERHADAP PERKEMBANGAN ANAK AUTIS DI SLB KHUSUS AUTISTIK FAJAR NUGRAHA SLEMAN, YOGYAKARTA
}

\author{
Dewanti, H.W., ${ }^{1}$ Machfud, S. ${ }^{2}$ \\ ${ }^{1}$ Mahasiswa Pendidikan Dokter Fakultas Kedokteran Universitas Islam Indonesia \\ ${ }^{2}$ Departemen Ilmu Kesehatan Anak Fakultas Kedokteran Universitas Islam Indonesia
}

\begin{abstract}
ABSTRAK
Latar Belakang

Prevalensi anak autis di seluruh dunia, termasuk Indonesia, dalam satu dekade ini semakin meningkat. Perbandingan anak autisme dengan anak normal di seluruh dunia saat ini telah mencapai 1:100. Sehingga perlu dicari inovasi-inovasi baru sebagai terapi untuk memperbaiki perkembangan anak autis. Salah satu terapi yang disarankan untuk anak autis adalah terapi diet bebas gluten dan kasein (GF/CF).
\end{abstract}

\section{Tujuan Penelitian}

Tujuan penelitian ini adalah untuk mengetahui hubungan antara diet bebas gluten dan kasein $(\mathrm{GF} / \mathrm{CF})$ terhadap perkembangan anak autis.

\section{Metode Penelitian}

Penelitian ini dilakukan dengan menggunakan metode rancangan penelitian cross sectional. Dengan menggunakan data primer yaitu data perkembangan anak autis berdasarkan checklist perkembangan ATEC dimana subyek dalam penelitian ini merupakan anak autis yang berada di SLB Khusus Autistik Fajar Nugraha Sleman dengan jumlah sampel yang digunakan adalah 10 orang.

\section{Hasil Penelitian}

Didapatkan hasil bahwa seluruh anak dengan kategori diet GF/CF yang baik memiliki perkembangan yang baik. Sedangkan dari 5 anak dengan kategori diet GF/CF yang tidak baik, terdapat 2 orang anak dengan perkembangan yang baik dan 3 orang anak dengan perkembangan yang tidak baik. Dari hasil uji statistik diperoleh nilai $\mathrm{p}$ adalah 0,038 dengan kriteria uji $\alpha=0,05$. Terdapat empat sel (100\%) yang memiliki nilai harapan (expected count) kurang dari 5. Berdasarkan hasil tersebut, interpretasi hasil uji adalah terdapat pengaruh yang signifikan diet bebas gluten dan kasein (GF/CF) terhadap perkembangan anak autisme.

\section{Kesimpulan}

Diet GF/CF mempengaruhi perkembangan anak autis.

Kata kunci : anak autis, SLB Khusus Autistik Fajar Nugraha Sleman. perkembangan, diet bebas gluten dan kasein. 


\section{ABSTRACT}

\section{Background}

The prevalence of children with autism around the world, including Indonesia, in the last decade is increasing. Comparison of children with autism with normal children around the world is 1:100. So, nowadays, there are many new innovations as a therapy to improve the development of children with autism. One of the recommended therapy for children with autism is gluten free and casein free diet $(G F / C F)$.

\section{Objectives}

This research aimed to find out the relationship among gluten-casein free diet and development of children with autism in SLB Autistic Fajar Nugraha Sleman, Yogyakarta.

\section{Methods}

This was a cross sectional descriptive study. The subjects in this research were children with autism who attended SLB Autistic Fajar Nugraha Sleman, Yogyakarta. Ten autism children were included in this study.The data analyses was done by Chi-square test.

\section{Result}

All children with good GF / CF had a good development. Two of Five children which with not good-GF / CF -categorical has well developed well and the rest has not well developed. The results of statistical test showed that there was a significant effect of gluten-casein free diet to development of autism ( $P=0,038 ; 95 \%$ Confidence interval 1,12 to 1,$88 ; \alpha=0,06$ and $R P>1$ ) in SLB Autistic Fajar Nugraha Sleman, Yogyakarta.

\section{Conclusion}

Our result showed that gluten-casein free diet influenced developmental outcome of children with autism.

Keywords : autism, SLB Autitics Fajar Nugraha Sleman, development, gluten free diet, casein free diet.

\section{PENDAHULUAN}

Dalam satu dekade terakhir, kejadian autisme sangat meningkat jumlahnya di seluruh penjuru dunia, begitu juga di Indonesia. Hasil penelitian terbaru menunjukkan satu dari 150 balita di Indonesia kini menderita autisme. Laporan terakhir badan kesehatan dunia (WHO) menyatakan perbandingan anak autisme dengan anak normal di seluruh dunia, termasuk Indonesia telah mencapai 1:100. ${ }^{1}$ Autisme adalah suatu gangguan perkembangan yang kompleks yang menyangkut komunikasi, interaksi sosial dan aktivitas imajinasi. Adanya gangguan pada setiap tahap akan menyebabkan 
hambatan pada tahap selanjutnya, sehingga deteksi dini, monitor dan stimulasi pertumbuhan dan perkembangan serta intervensi dini merupakan upaya penting untuk mengoptimalkan pertumbuhan dan perkembangan. $^{2}$

Diketahui pada penderita autisme terdapat gangguan pencernaan yang disebut leaky gut syndrome. Hal ini menyebabkan proses pencernaan menjadi tidak sempurna karena adanya gangguan produksi enzim pencernaan sehingga mengakibatkan protein-protein kompleks, yaitu gluten dan kasein, tidak dapat tercerna sempurna dan berubah menjadi peptida. Peptida tersebut masuk ke dalam darah dan dapat meracuni otak karena dapat berfungsi sebagai false transmitter yang berikatan dengan reseptor opioid dan memberikan efek terganggunya fungsi otak (persepsi, kognisi, emosi dan perilaku) sama seperti efek morfin. ${ }^{3}$

Diet bebas gluten dan kasein (GF/CF, Gluten Free Casein Free) adalah terapi bagi anak autis yang dilaksanakan dari dalam tubuh dan apabila dilaksanakan dengan terapi lain, seperti terapi perilaku, terapi wicara, dan terapi okupasi yang bersifat fisik akan lebih baik. Banyak anak autis yang mengalami perkembangan pesat dalam kemampuan bersosialisasi dan berkomunikasi setelah menjalani terapi $\mathrm{GF} / \mathrm{CF}{ }^{4}$

\section{METODE PENELITIAN}

Penelitian ini dilakukan dengan menggunakan metode rancangan penelitian cross sectional. Dengan menggunakan data primer yaitu data perkembangan anak autis berdasarkan checklist perkembangan ATEC dimana subyek dalam penelitian ini merupakan anak autis yang bersekolah di SLB Khusus Autistik Fajar Nugraha Sleman. Penelitian dilaksanakan di SLB Khusus Autistik Fajar Nugraha Sleman, Yogyakarta, pada bulan Desember 2012. Adapun kriteria inklusinya adalah :

a. Siswa yang terdaftar di SLB Khusus Autistik Fajar Nugraha sejak awal sampai akhir semester ganjil tahun ajaran 2012/2013.

b. Siswa dengan diagnosis autisme infantil.

c. Sampel penelitian bersedia dijadikan subyek penelitian.

Siswa yang baru terdaftar di SLB Khusus Autistik Fajar Nugraha pada pertengahan semester ganjil tahun ajaran 2012/2013 dan siswa dengan gangguan perkembangan pervasif selain autisme infantil tidak dimasukkan ke dalam penelitian. 
Data perkembangan anak autis diperoleh dari laporan perkembangan anak autis SLB Khusus Autistik Fajar Nugraha Sleman, baik dari kelompok yang menjalani terapi diet maupun tidak, oleh terapis yang sudah ahli melakukan diagnosis anak autis. Dikategorikan baik jika rata-rata skor perkembangan perilaku, komunikasi, akademik, motorik dan kemandirian meningkat daripada awal diagnosis, dan dikategorikan tidak baik jika rata-rata skor perkembangan perilaku, komunikasi, akademik, motorik dan kemandirian menurun daripada awal diagnosis. Anak kelompok diet baik dan kelompok diet tidak baik diberikan perlakuan yang sama, diluar perlakuan dietnya. Setiap anak mendapatkan terapi perilaku yang mengacu pada Applied Behavioral Analisys (ABA), terapi wicara, terapi okupasi, terapi fisik, sosial, bermain, dan terapi visual yang sama sesuai porsi masing-masing.

Data yang dikumpul diolah dan ditabulasikan dalam bentuk table distribusi frekuensi. Untuk mengetahui hubungan terapi GF/CF terhadap perkembangan anak autis dilakukan analisa data dengan menggunakan uji Chi Square.

\section{HASIL PENELITIAN}

Sampel penelitian ini adalah seluruh siswa SLB Khusus Autistik Fajar Nugraha Sleman, Yogyakarta, yang berusia 3-15 tahun dengan diagnosis autisme infantil. Setelah dilakukan pengambilan data sampel selama bulan Desember 2012 di SLB Khusus Autistik Fajar Nugraha Sleman, Yogyakarta, terdapat 13 anak autis terdaftar. Terdapat 2 anak yang keluar pada pertengahan semester dan 1 anak yang baru masuk pada pertengahan semester. Sehingga total sampel yang didapatkan adalah 10 orang anak.

\section{Karakteristik Sampel}

Siswa dibedakan menjadi dua kelompok usia yaitu kelompok usia $<5$ tahun dan kelompok usia $>5$ tahun. Berdasar hasil pengolahan data diketahui bahwa sebagian besar anak autis yang bersekolah di SLB Khusus Autistik Fajar Nugraha Sleman, Yogyakarta adalah >5 tahun (70\%). Dari data sampel yang didapatkan, usia sampel termuda adalah 3 tahun dan tertua berusia 15 tahun (Tabel 1).

Dari 10 sampel anak autis di SLB Khusus Autistik Fajar Nugraha Sleman, Yogyakarta, 8 orang anak $(80 \%)$ berjenis kelamin laki-laki dan hanya 2 orang anak 
(20\%) yang berjenis kelamin perempuan (Tabel 2).

Seluruh anak autis yang bersekolah di SLB Khusus Autistik Fajar Nugraha Sleman, Yogyakarta, didiagnosis autisme infantil pada usia $\leq 3$ tahun (100\%) (Tabel $3)$.

Tabel 1. Distribusi sampel berdasarkan usia anak autis.

\begin{tabular}{lcc}
\hline \multicolumn{1}{c}{ Usia } & Jumlah $(\mathbf{n})$ & Persentase $\mathbf{( \% )}$ \\
\hline$\leq 5$ tahun & 3 & 30 \\
$>5$ tahun & 7 & 70 \\
Total & $\mathbf{1 0}$ & $\mathbf{1 0 0}$ \\
\hline
\end{tabular}

Tabel 2. Distribusi sampel berdasarkan jenis kelamin anak autis

\begin{tabular}{lcc}
\hline $\begin{array}{c}\text { Jenis } \\
\text { Kelamin }\end{array}$ & Jumlah (n) & $\begin{array}{c}\text { Persentase } \\
(\boldsymbol{\%})\end{array}$ \\
\hline Laki-laki & 8 & 80 \\
Perempuan & 2 & 20 \\
Total & $\mathbf{1 0}$ & $\mathbf{1 0 0}$ \\
\hline
\end{tabular}

Tabel 3. Distribusi sampel berdasarkan usia pada awal diagnosis anak autis

\begin{tabular}{lcc}
\hline Usia & Jumlah $(\mathbf{n})$ & $\begin{array}{c}\text { Persentase } \\
(\mathbf{\%})\end{array}$ \\
\hline$\leq 3$ tahun & 10 & 100 \\
$>3$ tahun & 0 & 0 \\
Total & $\mathbf{1 0}$ & $\mathbf{1 0 0}$ \\
\hline
\end{tabular}

\section{Analisis Univariat}

Berdasarkan dietnya, sampel dikelompokkan menjadi kelompok baik bagi yang menjalankan diet GF/CF, dan kelompok tidak baik bagi yang tidak menjalankan diet $\mathrm{GF} / \mathrm{CF}$ atau hanya menjalankan salah satu diet bebas gluten saja atau bebas kasein saja. Pertimbangan diet GF/CF pada siswa SLB Khusus Autistik Fajar Nugraha berdasarkan kesepakatan dengan orang tua dan rekomendasi dokter. Didapatkan jumlah sama besarnya antara kelompok diet baik dan tidak baik, yakni masing-masing 5 orang anak (50\%) (Tabel 4).

Berdasarkan penilaian perkembangannya menggunakan ATEC, didapatkan 7 orang anak (70\%) dengan kategori perkembangan yang baik (Tabel 5).

Tabel 4. Distribusi sampel berdasarkan diet bebas gluten dan kasein (GF/CF)

\begin{tabular}{lcc}
\hline GF/CF & $\begin{array}{l}\text { Jumlah } \\
(\mathbf{n})\end{array}$ & $\begin{array}{l}\text { Persentase } \\
(\boldsymbol{\%})\end{array}$ \\
\hline Baik & 5 & 50 \\
Tidak Baik & 5 & 50 \\
Total & $\mathbf{1 0}$ & $\mathbf{1 0 0}$ \\
\hline
\end{tabular}

Tabel 5. Distribusi sampel berdasarkan perkembangan anak autis.

\begin{tabular}{lcc}
\hline Perkembangan & Jumlah (n) & $\begin{array}{c}\text { Persentase } \\
(\boldsymbol{\%})\end{array}$ \\
\hline Baik & 7 & 70 \\
Tidak Baik & 3 & 30 \\
Total & $\mathbf{1 0}$ & $\mathbf{1 0 0}$ \\
\hline
\end{tabular}

\section{Analisis Bivariat}

Pada Tabel 6 dapat diketahui bahwa seluruh anak dengan kategori diet $\mathrm{GF} / \mathrm{CF}$ yang baik memiliki perkembangan yang baik juga. Sedangkan dari 5 anak dengan kategori diet GF/CF yang tidak baik, terdapat 2 orang anak dengan 
perkembangan yang baik dan 3 orang anak dengan perkembangan yang tidak baik.

Tabel 6. Hubungan diet bebas gluten dan kasein (GF/CF) terhadap perkembangan anak autis di SLB Khusus Autistik Fajar Nugraha Sleman, Yogyakarta.

\begin{tabular}{lccc}
\hline & \multicolumn{3}{l}{ Perkembangan } \\
Anak Autis & Total \\
& Baik & $\begin{array}{c}\text { Tidak } \\
\text { Baik }\end{array}$ & \\
\hline Baik & 5 & 0 & 5 \\
Tidak Baik & 2 & 3 & 5 \\
Total & $\mathbf{7}$ & $\mathbf{3}$ & $\mathbf{1 0}$ \\
\hline
\end{tabular}

\section{PEMBAHASAN}

Data yang telah didapatkan kemudian dianalisis dengan menggunakan analisa Chi Square dan hasil analisanya didapatkan hasil terdapat pengaruh yang signifikan diet bebas gluten dan kasein terhadap perkembangan anak autis dengan nilai $\mathrm{p}=0.038(\mathrm{p}<0,05)$, maka dengan hasil tersebut dapat diketahui bahwa hipotesis dari penelitian ini bermakna. Pada uji normalitas diketahui distribusi data yang tidak normal, sehingga uji korelasi digunakan uji Spearman, dan didapatkan hasil terdapat empat sel $(100 \%)$ yang memiliki nilai harapan (expected count) kurang dari 5, 95\% Confidence Interval 1,12 - 1,88, dan $R P>1 \quad(2,5)$, sehingga terbukti bahwa terdapat pengaruh yang signifikan diet bebas gluten dan kasein terhadap perkembangan anak autis. Atau dapat dikatakan bahwa diet bebas gluten dan kasein merupakan salah satu terapi yang cukup efektif bagi perkembangan anak autis.

Hasil penelitian ini sesuai dengan teori-teori para ahli tentang diet GF/CF sebagai terapi bagi anak autis. Dari hasil penelitian dapat disimpulkan bahwa sampel anak autis dengan terapi diet GF/CF cenderung memiliki perkembangan yang lebih baik daripada anak autis tanpa diet $\mathrm{GF} / \mathrm{CF}{ }^{5}$

Para ahli sepakat, penyandang autis sebaiknya berdiet gluten dan kasein yang dikenal diet GF/CF (gluten free casein free). Selain diyakini dapat memperbaiki gangguan pencernaan, juga bisa mengurangi gejala atau tingkah laku autistik anak. ${ }^{6}$ Meski sama-sama keluarga protein, gluten dan kasein berbeda. Gluten adalah protein yang berasal dari keluarga gandum-ganduman, semisal terigu, wheat, oat, dan barley, sementara kasein berasal dari susu sapi. Yang jelas, kedua jenis protein ini sulit dicerna. ${ }^{7}$

Karena banyak anak autis mengalami defisiensi DDP-IV (dipeptidil peptidase IV) dan disertai dengan leaky gut syndrome, maka sejumlah substansi peptida yang seharusnya tidak bisa diterima tubuh, seperti gluten dan kasein, dapat terabsorbsi 
masuk ke aliran darah. Peptida-peptida ini bila terbawa ke otak akan berfungsi sebagai false transmitter yang berikatan dengan reseptor opioid, dan memiliki efek seperti opioid dengan potensi berlipat dibanding morfin. Substansi alamiah yang serupa dengan morfin ini cenderung meracuni anak-anak tersebut dan mempengaruhi motivasi, emosi, persepsi, respon, dan perkembangan normal dari otak mereka. Opioid peptides menstimulasi sinaps saraf mereka secara berlebihan dan memblokir transmisi sinyal ke otak. ${ }^{8}$

Diet bebas gluten dan kasein (GF/CF, Gluten Free Casein Free) adalah terapi bagi anak autis yang dilaksanakan dari dalam tubuh dan apabila dilaksanakan dengan terapi lain, seperti terapi perilaku, terapi wicara, dan terapi okupasi yang bersifat fisik akan lebih baik. Banyak anak autis yang mengalami perkembangan pesat dalam kemampuan bersosialisasi dan berkomunikasi setelah menjalani terapi $\mathrm{GF} / \mathrm{CF}{ }^{9}$

Diet GF/CF sebenarnya merupakan terapi penunjang yang tidak dapat bersifat langsung menyembuhkan autisme, namun diharapkan dapat mempercepat proses penyembuhan. Setiap anak autis memiliki derajat autisme yang berbeda, sehingga penerapan terapi diet $\mathrm{GF} / \mathrm{CF}$ ini bersifat individual dan tidak bisa diseragamkan. ${ }^{10}$

\section{KESIMPULAN}

Berdasarkan hasil penelitian dan pembahasan mengenai pengaruh diet bebas gluten dan kasein terhadap perkembangan anak autis di SLB Khusus Autistik Fajar Nugraha Sleman, Yogyakarta, didapatkan hasil bahwa terdapat pengaruh yang signifikan antara diet bebas gluten dan kasein terhadap perkembangan anak autis berdasarkan nilai $\mathrm{p}<0,05(0,038)$. Sehingga dapat disimpulkan bahwa terdapat pengaruh diet bebas gluten dan kasein terhadap perkembangan anak autis di SLB Khusus Autistik Fajar Nugraha Sleman, Yogyakarta.

\section{SARAN}

1. Bagi instansi, perlu mengoptimalkan terapi diet bebas gluten dan kasein kepada siswa-siswi nya dan melakukan kontrol diet secara periodik dengan menggunakan Food Frequency Questioner.

2. Bagi instansi, dapat menggunakan Autism Treatment Evaluation Checklist (ATEC) dari Autism Research Institute (ARI) untuk menilai perkembangan siswa-siswi nya secara periodik. 
3. Bagi peneliti, perlu dilakukan rancangan penelitian dengan metode Case Control dan Cohort dan dengan jumlah sampel yang lebih besar untuk mendapatkan hasil yang lebih mendalam mengenai pengaruh diet bebas gluten dan kasein terhadap perkembangan anak autis.

4. Bagi peneliti lain agar dapat mengkaji ulang variabel lain yang belum diteliti sebagai variabel tambahan yang kemungkinan berpengaruh terhadap perkembangan anak autis dan dapat melanjutkan penelitian terhadap faktorfaktor tersebut.

\section{DAFTAR PUSTAKA}

1. American Psychiatric Association. Diagnostic and Statistical Manual of Mental Disorder, $4^{\text {th }}$.ed. Washington, 2000.

2. Danuatmaja B. Terapi Anak Autis di Rumah. Jakarta : Puspa Swara, 2003.

3. Handojo Y. Autisme, Jakarta : PT. Buana Ilmu Populer Kelompok Gramedia, 2008.

4. Harumi J., et al. Evaluation of an association between gastrointestinal symptoms and cytokine production against common dietary proteins in children with autism spectrum disorders. J. Pediatrics 2005; 146.

5. Elizabeth S. Eating for Autism: The Revolutionary 10-Step Nutrition Plan to Help Treat Your Child's Autism, Asperger's, or ADHD. Massachusetts: Da Capo Press, 2009.

6. Whiteley P., Shattock P, Carr K, Hooper M and Todd L. How Could a Gluten- and Casein-Free Diet Ameliorate. Symptoms Associated with Autism Spectrum
Conditions?, Autism Insights 2010;(2):3953.

7. Seroussi. Asupan Gluten dan Casien pada anak autism.Jakarta, 2004.

8. Shatock P, Ariani E. Langkah Awal Menanggulangi Autisme dengan Memperbaiki Metabolisme Tubuh. Jakarta: Nirmala,2002.

9. Handojo Y. Petunjuk Praktis dan Pedoman Materi Untuk Mengajar Anak Normal, Autis dan Perilaku Lain. Jakarta: Bhuana Ilmu Populer, 2003.

10. Danuatmaja B. Menu Autis : Panduan Diit Tepat Untuk Anak Autis. Jakarta: Puspa Swara, 2004. 